\title{
Genetic variation within and between populations of the asexual plant Puccinellia $x$ phryganodes
}

\author{
R. L. JEFFERIES \\ Department of Botany, University of Toronto, Toronto, Ont., Canada M5S 1AI \\ AND L. D. GOTTLIEB \\ Department of Genetics, University of California, Davis, CA, U.S.A.
}

Puccinellia x phryganodes (Trin.) Scriber and Merr is widely distributed in Arctic salt marshes. In North America the species, which is capable of extensive clonal growth, appears to be a sterile triploid $(2 \mathrm{n}=$ $21)$; seed set has never been observed. Consequently it was predicted that the level of genetic variation would be low, both within and between populations. Examination of electrophoretic mobilities of isozymes of 12 enzyme systems in plants from three widely separated populations in Arctic Canada indicated a high level of variability both within and between the populations. The unexpected discovery of significant amounts of genetic variability suggests that sexual processes occur in this species.

\section{Introduction}

Puccinellia X phryganodes (Trin.) Scriber and Merr is the only circumpolar representative of the genus (Sorensen 1953). Although present in the high Arctic regions of North America, Greenland, and Eurasia, it occurs as far south as James Bay $\left(53^{\circ} \mathrm{N}\right)$ and is widespread around the shores of Hudson Bay in eastern North America (Hultén 1968; Dore and McNeill 1980). The species is restricted to coastal salt flats, where frequently it grows in pure stands, especially at the seaward end of marshes. Individuals are capable of extensive vegetative growth, as the stoloniferous growth habit is well developed. The stolons frequently produce short, sprawling extraaxillary shoots, which is unusual among grasses (Dore and McNeill 1980). Although plants undergo vigorous vegetative growth, flowering is infrequent and seed set has never been observed (Anderson and Hesselman 1900; Holmberg 1926; Polunin 1940; Lid 1952; Sorensen 1953; Dore and McNeill 1980). Bowden (1961) has reported that plants from eastern North America are sterile triploids $(2 \mathrm{n}=$ 21), although cytological evidence indicates that some populations in northern Europe are tetraploid (Sorensen 1953). Variation in leaf epidermal characteristics between

populations has been reported by Sorensen (1953). The four morphological "types" which he recognized are from the following regions: Novaya Zernlya and Spitsbergen, Fennoscandia and Siberia, Beringia, and lastly Greenland and Canada. We predicted that the absence of seed set would result in a low level of genetic variability in populations representative of a morphological type from a particular region. Accordingly, we examined the levels of genetic variation by electrophoretic methods in three populations of Puccinellia $x$ phryganodes from the Canadian Arctic. This was of particular interest as the identification of the sterile triploid was based on material collected from within this region (e.g., Baffin Island, Southampton Island, District of Keewatin) (Bowden 1961).

\section{Material and methods:}

Turfs $(5 \times 5 \times 5 \mathrm{~cm}$ ) of Puccinellia X phryganodes were collected from foreshores at the following locations: La Pétrouse Bay, Man. (58 $4^{\circ} \mathrm{N}$, 
$\left.94^{\circ} 4^{\prime} \mathrm{W}\right)$, on the shore of Hudson Bay;

$\left(69^{\circ} 4^{\prime} \mathrm{N}, 133^{\circ} 001^{\prime} \mathrm{W}\right)$, and Alexandra Fiord, Ellesmere Island, N.W.T. ( $\left.78^{\circ} 53^{\prime} \mathrm{N} ; 75^{\circ} 55^{\prime} \mathrm{W}\right)$.

The vegetation at these sites has been described elsewhere (Jefferies 1977; Jefferies et al. 1979; Svoboda and Freedman 1981). The 15, 10 , and 5 turfs, respectively, which were obtained from the three locations, were dug at intervals of approximately $100 \mathrm{~m}$ along each foreshore. As indicated later, some turfs
Tuktoyaktuk, N.W.T.

contained more than one genotype. The turfs were packed and sent by air freight to Davis, CA. On arrival the turfs were placed in small beakers which contained diluted (10\%) Hoagland's solution. Subsequently the beakers were placed in a growth cabinet $\left(16 \mathrm{~h}\right.$ day; $15^{\circ} \mathrm{C}$ day : $10^{\circ} \mathrm{C}$ night) for 3 weeks to allow the plants to develop new shoots. Water was added to the beakers as appropriate.

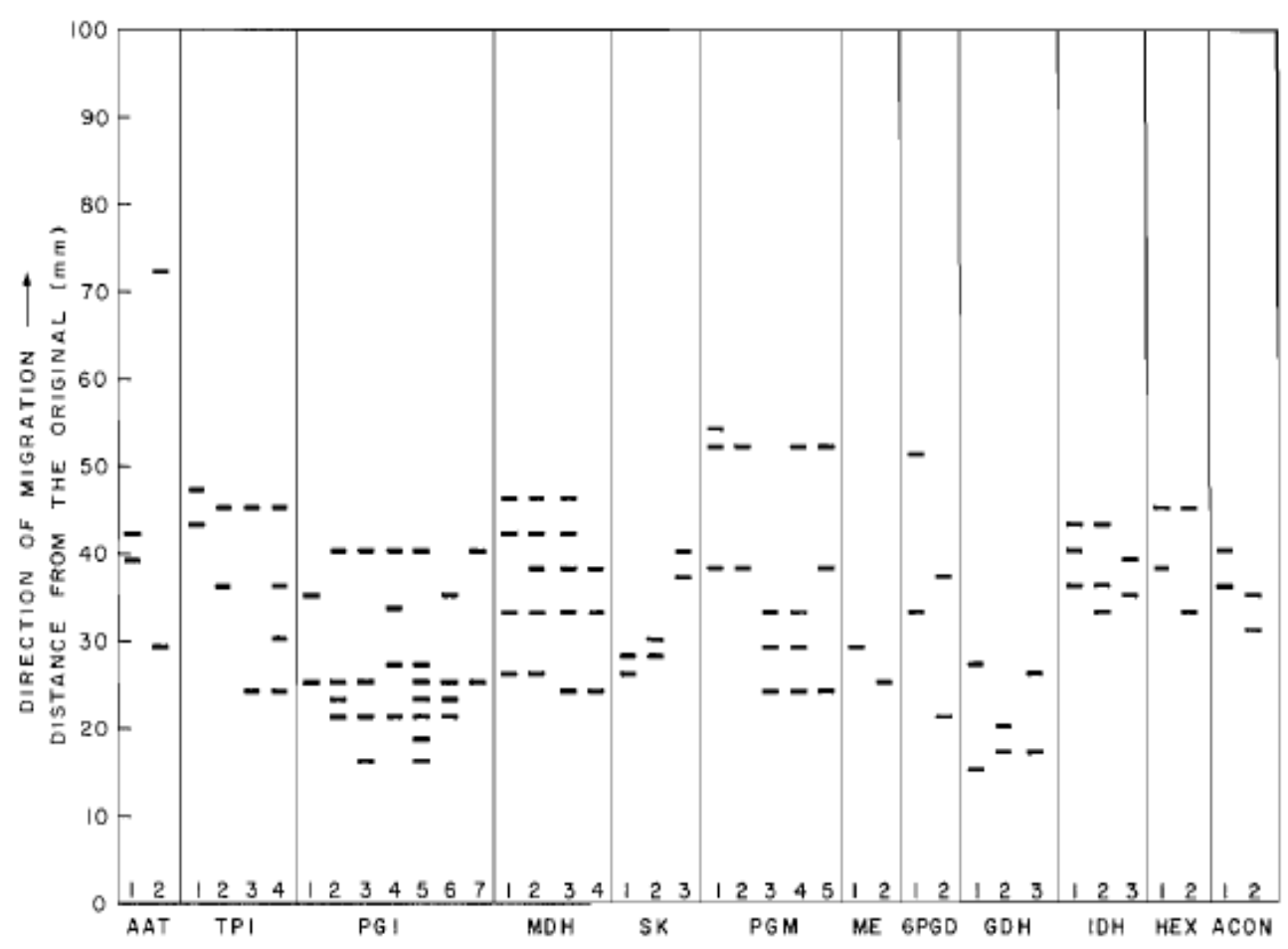

FIG. 1. Isozymic patterns in Puccinellia $\times$ phryganodes from La Pérouse Bay, Man., Tuktoyaktuk, N.W.T., and Alexandra Fiord, N.W.T.

The crude extracts for electrophoresis were obtained from new shoots, which were crushed in small plastic weighing boats containing 0.2 $\mathrm{rnL}$ of cold extraction buffer and $10 \mathrm{mg}$ of solid polyvinyl polypyrrolidone (Gottlieb 1982). The extracts in each boat were chilled on ice until required. Electrophoresis was conducted in $12.8 \%$ starch gels, utilizing the methods and procedures described in Gottlieb (1981 )T. he particular gels and electrode buffer combination for each enzyme are described fully therein, except that isocitric dehydrogenase and hexokinase were run on system IV (Gottlieb 1981a), which resulted in an improved resolution of the bands for these two enzymes. The following seven enzymes were 
investigated in all material:

phosphoglucomutase (EC 2.7.5. I), phosphoglucose isomerase (EC 5.3.1.9), malic enzyme (EC 1.1.1.40), malate dehydrogenase (EC 1.1.1.37), shikimate dehydrogenase (EC 1.1.1.25), triose phosphate isomerase (EC 5.3.1. I), and aspartate amino transferase (EC 2.6.1.1). Three additional enzymes examined in material from Alexandra Fiord and La PCrouse Bay were 6-phosphogluconate dehydrogenase (EC 1.1.1 A), glutamate dehydrogenase (EC 1.4.1.2), and isocitric dehydrogenase (EC 1.1.1.41).

Hexokinase (EC 2.7.1.1) and aconitase (EC 4.2.1.2) were also assayed in plants from La Pérouse Bay. Electrophoretic mobility of enzyme systems was also examined in different shoots from a single turf to establish that the electrophoretic patterns of enzymes from different shoots within a turf were uniform. Enzymatic preparations were made from shoots of three turfs that were collected at La Pérouse Bay and two from Alexandra Fiord. All isozymes migrated towards the anode. Standard assay

\section{Results:}

The isozyme patterns observed in Puccinellia $X$ phryganodes are generally interpretable on the basis of those observed in sexual diploid species in which the number of isozymes for each of the enzymes assayed and their genetic control are reasonably well understood (Gottlieb 1981 b, 1982). Thus, many of the individuals of $P . X$ phryganodes displayed the same minimum number of two isozymes for TPI, PGI, PGM, and 6 PGDH. This is characteristic of homozygous diploid plants; one isozyme is located in the plastids and the other in the cytosol. The multiple bands of activity for these enzymes in some plants probably reflect the expression of homologous gene loci in its polyploid genome that specify electrophoretically distinguishable variants. those observed in sexual diploid species in which the number of isozymes for procedures were used to determine their electrophoretic mobilities (Brewer 1970; Shaw and Prasad 1970; Weeden and Gottlieb 1980). Only those enzymes which were separated by electrophoresis into cleanly resolved bands of activity were used. Although plants of Puccinellia $x$ phryganodes flower rarely, seven flowering shoots from widely separated individuals were collected at La Pérouse Bay to determine whether the pollen was sterile. The grains were stained with acetocarmine for $30 \mathrm{~s}$ and then examined under a microscope. The percentage of badly formed grains that failed to take up the stain was recorded. In addition, the somatic chromosome number of two plants from La Pérouse Bay was determined as a further check that the material was triploid. Developing root tips were fixed in acetic alcohol (4:2 v / v glacial acetic acid and ethanol). The chromosomes were stained with a solution of Feulgen stain before tissue squashes were prepared and the chromosomes were counted.

each of the enzymes assayed and their genetic control are reasonably well understood (Gottlieb 1981 b, 1982). Thus, many of the individuals of $P$. $X$ phryganodes displayed the same minimum number of two isozymes for TPI, PGI, PGM, and 6PGDH. This is characteristic of homozygous diploid plants; one isozyme is located in the plastids and the other in the cytosol. The multiple bands of activity for these enzymes in some plants probably reflect the expression of homologous gene loci in its polyploid genome that specify electrophoretically distinguishable variants. However, the purpose of the present study was not to estimate the number of loci coding particular enzymes or to assess the allelism of particular variants. 
TABLE 1. Distribution of isozyme patterns, with reference to Fig. 1, in individuals of Puccinellia phryganodes from La Pérouse Bay, Man., Tuktoyaktuk, N.W.T., and Alexandra Fiord, N.W.T.

\begin{tabular}{|c|c|c|c|c|c|c|c|c|c|c|c|c|c|}
\hline & \multirow[b]{2}{*}{ Individual } & \multicolumn{12}{|c|}{ Isozymic pattern } \\
\hline & & AAT & TPI & PGI & $\mathrm{MDH}$ & SKDH & PGM & $\mathrm{ME}$ & $6 \mathrm{PGD}$ & $\mathrm{GDH}$ & IDH & HEX & ACON \\
\hline \multirow[t]{15}{*}{ La Pérouse Bay } & 1 & 1 & 3 & 1 & 2 & 1 & 5 & 1 & 2 & 1 & 2 & 1 & 1 \\
\hline & 2 & 1 & 2 & 1 & 3 & 1 & 3 & 1 & 2 & 2 & 1 & 1 & 1 \\
\hline & 3 & 2 & 1 & 3 & 1 & 1 & 4 & 1 & 1 & 3 & 2 & 1 & 1 \\
\hline & 4 & 2 & 1 & 6 & 1 & 1 & 2 & 1 & 1 & 3 & 2 & 1 & 1 \\
\hline & 5 & 2 & 1 & 4 & 1 & 1 & 2 & 1 & 1 & 3 & 2 & 1 & 1 \\
\hline & 6 & 2 & 1 & 5 & 1 & 3 & 2 & 2 & 1 & 3 & 1 & 2 & 2 \\
\hline & 7 & 2 & 1 & 5 & 1 & 2 & 2 & 1 & 1 & 2 & 1 & 1 & 1 \\
\hline & 8 & 2 & 1 & 5 & 1 & 1 & 2 & 1 & 1 & 3 & 2 & 1 & 1 \\
\hline & 9 & 2 & 1 & 2 & 1 & 2 & 2 & 1 & 1 & 3 & 1 & 1 & 1 \\
\hline & 10 & 2 & 1 & 3 & 1 & 2 & 2 & 1 & 1 & 3 & 1 & 1 & 1 \\
\hline & 11 & 2 & 1 & 6 & 1 & 1 & 2 & 1 & 1 & 3 & 2 & 1 & 1 \\
\hline & 12 & 2 & 1 & 5 & 1 & 2 & 2 & 1 & 1 & 3 & 1 & 1 & 1 \\
\hline & 13 & 2 & 1 & 5 & 1 & 1 & 2 & 1 & 1 & 3 & 2 & 1 & 1 \\
\hline & 14 & 1 & 4 & 6 & 3 & 1 & 3 & 1 & 2 & 1 & 2 & 1 & 1 \\
\hline & 15 & 2 & 1 & 3 & 1 & 1 & 2 & 1 & 1 & 3 & 2 & 1 & 1 \\
\hline \multirow[t]{5}{*}{ Alexandra Fiord } & 1 & 1 & 1 & 6 & 1 & 1 & 2 & 1 & 1 & 3 & 3 & & \\
\hline & 2 & 1 & 1 & 6 & 1 & 1 & 2 & 1 & 1 & 3 & 3 & & \\
\hline & 3 & 1 & 1 & 6 & 1 & 1 & 2 & 1 & 1 & 3 & 3 & & \\
\hline & 4 & 1 & 1 & 6 & 1 & 1 & 2 & 1 & 1 & 3 & 3 & & \\
\hline & 5 & 1 & 1 & 6 & 1 & 1 & 2 & 1 & 1 & 3 & 3 & & \\
\hline \multirow[t]{10}{*}{ Tuktoyaktuk } & 1 & 1 & 3 & 1 & 3 & 2 & 3 & 2 & & & & & \\
\hline & 2 & 2 & 1 & 7 & 1 & 1 & 2 & 1 & & & & & \\
\hline & 3 & 2 & 1 & 3 & 1 & 1 & 2 & 1 & & & & & \\
\hline & 4 & 1 & 4 & 1 & 4 & 2 & 3 & 2 & & & & & \\
\hline & 5 & 2 & 1 & 3 & 2 & 1 & 2 & 1 & & & & & \\
\hline & 6 & 1 & 4 & 1 & 4 & 2 & 3 & 2 & & & & & \\
\hline & 7 & 1 & 4 & 1 & 4 & 2 & 3 & 2 & & & & & \\
\hline & 8 & 2 & 1 & 3 & 2 & 1 & 1 & 1 & & & & & \\
\hline & 9 & 1 & 4 & 1 & 3 & 2 & 3 & 2 & & & & & \\
\hline & 10 & 2 & 1 & 3 & 1 & 2 & 1 & 1 & & & & & \\
\hline
\end{tabular}

Such studies would require very large samples and may not be feasible in this largely asexual species. Rather we wished to determine the extent of genetic identity among individuals and populations.

The major result was the discovery of a large amount of electrophoretic variability both within and between the populations sampled. Five of the 12 enzymes examined showed two patterns (AAT, ME, 6PGDH, HEX, ACON), three showed three patterns (SKDH, GDH, IDH), two showed four patterns (TPI, MDH), PGM had five patterns, and PGI, the most variable enzyme, exhibited seven patterns (Fig. 1). Thus summed for all enzymes, a total of 39 patterns was recognized. Table 1 shows the electrophoretic patterns for the enzymes displayed by each individual. Thirteen different sets of patterns were observed among the 15 plants sampled from La PCrouse Bay. Only two pairs of plants were identical ( 4 and 11 , and 8 and 13 ). At Tuktoyaktuk, eight different sets of patterns were found among the 10 plants. No variation was detected among the five plants sampled from Alexandra Fiord. Table 2 summarizes the data from Table 1 and makes it possible to compare the three populations on an enzyme by enzyme basis for 7 of the enzymes, and the La Pérouse Bay and Alexandra Fiord populations for 10 of the enzymes. In the three populations the same pattern for TPI was the most frequent. The patterns of MDH and ME which were most abundant in plants from La Pétrouse Bay shared this ranking with other patterns in material from Alexandra Fiord and Tuktoyaktuk. Of the 


\begin{tabular}{|c|c|c|c|}
\hline & & Site & \\
\hline $\begin{array}{l}\text { Isozyme } \\
\text { pattern }\end{array}$ & La Pérouse Bay & Tuktoyaktuk & $\begin{array}{c}\text { Alexandra } \\
\text { Fiord }\end{array}$ \\
\hline $\begin{array}{c}A A T \\
1 \\
2\end{array}$ & $\begin{array}{l}0.20 \\
0.80\end{array}$ & $\begin{array}{l}0.50 \\
0.50\end{array}$ & 1.00 \\
\hline $\begin{array}{r}\text { TPF } \\
1 \\
2 \\
3 \\
4\end{array}$ & $\begin{array}{l}0.80 \\
0.07 \\
0.07 \\
0.07\end{array}$ & $\begin{array}{l}0.50 \\
0.10 \\
0.40\end{array}$ & 1.00 \\
\hline $\begin{array}{c}\text { PGI } \\
1 \\
2 \\
3 \\
4 \\
5 \\
6 \\
7\end{array}$ & $\begin{array}{l}0.13 \\
0.07 \\
0.20 \\
0.07 \\
0.33 \\
0.13 \\
0.10\end{array}$ & $\begin{array}{l}0.50 \\
0.40 \\
\square \\
-\end{array}$ & 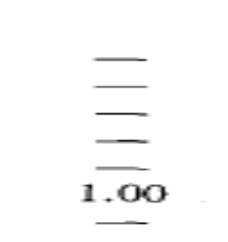 \\
\hline $\begin{array}{c}\text { MDH } \\
1 \\
2 \\
3 \\
4\end{array}$ & $\begin{array}{l}0.80 \\
0.07 \\
0.13 \\
\end{array}$ & $\begin{array}{l}0.30 \\
0.20 \\
0.20 \\
0.30\end{array}$ & $\frac{1.00}{-}$ \\
\hline $\begin{array}{l}\text { SKDH } \\
\quad 1 \\
2 \\
3\end{array}$ & $\begin{array}{l}0.67 \\
0.27 \\
0.07\end{array}$ & $\begin{array}{l}0.40 \\
0.60 \\
\end{array}$ & 1.00 \\
\hline $\begin{array}{c}\text { PGM } \\
1 \\
2 \\
3 \\
4 \\
5\end{array}$ & $\begin{array}{l}0.73 \\
0.13 \\
0.07 \\
0.07 \\
0.07\end{array}$ & $\begin{array}{l}0.20 \\
0.30 \\
0.50 \\
-\end{array}$ & $\overline{1.00}$ \\
\hline $\begin{array}{r}M E \\
1 \\
2\end{array}$ & $\begin{array}{l}0.93 \\
0.07\end{array}$ & $\begin{array}{l}0.50 \\
0.50\end{array}$ & 1.00 \\
\hline $\begin{array}{c}\text { GPGDH } \\
1 \\
2\end{array}$ & $\begin{array}{l}0.80 \\
0.20\end{array}$ & n.a. & 1.00 \\
\hline $\begin{array}{c}\text { GDH } \\
1 \\
2 \\
3\end{array}$ & $\begin{array}{l}0.13 \\
0.13 \\
0.73\end{array}$ & n.a. & $\overline{1.00}$ \\
\hline $\begin{array}{c}\text { WH } \\
1 \\
2 \\
3\end{array}$ & $\begin{array}{l}0.40 \\
0.60 \\
-\end{array}$ & na. & $\overline{1.00}$ \\
\hline
\end{tabular}

two patterns of AAT, either one or the other predominated in populations from La Pérouse Bay and Alexandra Fiord, whereas the frequency of each was equal among individuals from Tuktoyaktuk. For SKDH and PGM the same patterns were at a higher frequency in the La Pérouse Bay and Alexandra Fiord populations, but the most frequent patterns in the Overall for the seven enzyme systems individuals from La Pérouse Bay had the largest number of patterns (24 compared with 16
Tuktoyaktuk population were different. The most frequent pattern for PGI, which was at a high frequency, was different in the three populations. In the case of 6PGDH and GDH, the Alexandra Fiord population was fixed for the pattern which was most common in the La Pétrouse Bay plants.

patterns in plants from Tuktoyaktuk). Individuals from Tuktoyaktuk showed three patterns not present in plants from La Pétrouse 
Bay. Patterns for 8 out of 10 enzymes which were most frequent in material from La Ptrouse Bay were present in all individuals from Alexandra Fiord. On the basis of these results, individuals from Alexandra Fiord were more similar to those at La Pétrouse Bay than plants from Tuktoyaktuk. To evaluate whether variation was present among individuals from the same turfs, a number of shoots were examined within two turfs from Alexandra Fiord and three from La Ptrouse Bay (Table 3). The 16 shoots examined from Alexandra Fiord were the same. The 10 shoots examined from turfs 1 and 3 from La PCrouse Bay were the same, but three different sets of patterns were discovered among the four shoots of turf 2. Examination of pollen taken from one or two florets of each of the seven flowering shoots of $P . x$ phryganodes from La Pétrouse Bay indicated that all pollen was sterile. In addition, the chromosome count of root tips from the two plants examined was $2 n=21$, thereby confirming Bowden's (1961) earlier results.

\section{Discussion:}

The initial hypothesis was that as a result of the capacity for extensive clonal growth, the absence of seed set, and the apparent high sterility of the North American populations due to their hybrid origin, the

TABLE 3. Distribution of isozyme patterns, with reference to Fig. 1, of Puccinellia phryganodes in individual shoots from three turfs $(1,2,3)$ taken from La Pérouse Bay, Man., and two turfs (4 and 5) taken from Alexandra Fiord, N.W.T.

\begin{tabular}{lccccccc}
\hline \hline & \multicolumn{7}{c}{ Isozyme pattern } \\
\cline { 2 - 8 } Individuals & AAT & TPI & PGI & MDH & SKDH & PGM & ME \\
\hline $1 a-f$ & 2 & 1 & 3 & 1 & 1 & 2 & 1 \\
$2 a$ & 2 & 1 & 3 & 2 & 1 & 2 & 1 \\
$2 b$ & 2 & 1 & 3 & 2 & 1 & 2 & 1 \\
$2 c$ & 2 & 1 & 3 & 1 & 1 & 2 & 1 \\
$2 d$ & 1 & 2 & 1 & 1 & 1 & 3 & 2 \\
$3 a-d$ & 2 & 1 & 3 & 1 & 1 & 2 & 1 \\
$4 a-f$ & 1 & 1 & 6 & 1 & 1 & 2 & 1 \\
$5 a-j$ & 1 & 1 & 6 & 1 & 1 & 2 & 1 \\
\hline
\end{tabular}

level of genetic variability in Puccinellia $X$ phryganodes was likely to be low. The results allow a clear rejection of the hypothesis. Furthermore, with increased sample sizes the number of isozyme patterns detected in each population would almost certainly rise. Since the electrophoretic variation can be equated with different genotypes (although their precise nature cannot be specified), the species in North America does not consist of one or even a few genets that have become established throughout the continent as a result of clonal growth. Rather most individuals are genetically unique. The uniformity of material from Alexandra Fiord may simply reflect inadequate sampling. Alternatively, in these high-latitude environments only certain genotypes may survive. Harberd (1967) has shown that an individual genotype of another grass, Holcus mollis L., may spread over a considerable area as a result of clonal growth. However, it is now obvious that it would be worthwhile to reexamine such clones by electrophoresis to test whether they actually are single genotypes. The fact that there is such a range of variation in the triploid material from La Pérouse Bay and the presumed triploids from Tuktoyaktuk implies that if the species in North America has a hybrid origin, the hybrid may have been produced on a number of occasions in different 
areas of the Arctic. However, a simpler alternative hypothesis is that the genetic variation results from sexual reproduction and that seed set take place as a rare event. The wide distribution of certain genotypes (i.e., individuals 2 and 15 from Tuktoyaktuk and La Pérouse Bay respectively) may result from "ice rafting." Frozen sediment on the shore is frequently uplifted by pack ice and carried to another locality. Sdrensen (1953) records the finding of live stolons of $P . x$ phryganodes in pack ice of the Arctic Ocean gyro. The stolons commenced growth when planted. The implication of this finding is that a particular genotype may spread widely in this region pollen of inflorescences collected at La Pkrouse Bay was apparently sterile, Sorensen (1953) indicated that $1-2 \%$ of pollen was viable in some inflorescences which he examined. An extreme example was material collected from Beringia, in which the viability of pollen reached $50 \%$ in some flowers. Given the presence of a sufficient number of inflorescences at a site and provided further developmental processes do not stop fertilization and embryo development, even with a level of pollen viability of $2 \%$, it seems likely that some viable seeds are produced. Our results suggest that known sterile triploid hybrids (Grant 1981) might well be examined by electrophoresis to assess genetic variability. Relatively few investigations have used genetic markers to examine variation in clones of perennial plants. In the other studies of this type (Wu et al. 1975; Cahn and Harper 1976; Gray et al. 1979; Silander 1979), the plants investigated were fully sexual, unlike Puccinellia $x$ phryganodes. We know of one other study similar to that described in this paper. Gel electrophoresis has been used to detect some variation (four genotypes out of 284 plants sampled) in the apomictic triploid species Taraxacum ofjicinale (Solbrig and Simpson 1974). The actual cause of the very high genetic variability in Puccinellia $X$ phryganodes remains to be determined. The occasional production of U.S.A. 78: 3726-3729. 1981 b. Electrophoretic evidence and plant populations. Prog. viable gametes and perhaps rare events of somatic mutation may be contributing causes. Regardless of the genesis of variability, its presence suggests that genetic variation may play an important role in the adaptation of the species.

\section{Acknowledgements}

We thank J. Svoboda, S. M. Cargill, D. Bazely, B. Erickson, and G. Hobson for collecting plants of Puccinellia $x$ phryganodes and arranging the air freight of the samples. The material from Alexandra Fiord was kindly analyzed by E. Pichersky. This work was undertaken while one of us (R.L.J.) was on sabbatical leave at the Department of Genetics, University of California at Davis. The research was supported by a Natural Sciences and Engineering Research Council of Canada grant to R.L.J. and a National Science Foundation grant DEB 79-22196 to L.D.G.

ANDERSONG, ., and H. HESSELMAN19. 00. Birrag till Kannedomen om Spetsberginsoch Beeren Eilands karlvaxtflora. Bih. Kongl. Sven. Vet. Akad. Handl. 26(III): 1.

BOWDENW, . M. 1961. Chromosome numbers and taxonomic notes on northern grasses. IV. Tribe Festuceae: Poa and Puccinellia. Can. J. Bot. 39: 123-138.

BREWERG, . J. 1970. An introduction to isozyme techniques. Academic Press, New York. CAHNM, . G., and J. L. HARPER1. 976. The biology of the leaf mark polymorphism in Trifolium repens $L$. 1. Distribution of phenotypes at a local scale. Heredity, 37: 309-325.

DORE, W. G., and J. MCNEILL. 1980. Grasses of Ontario. Research Branch, Agriculture Canada, Ottawa, Monograph 26.

GOTTLIEBL, . D. 1981 a . Gene number in species of Astereae that have different chromosome numbers. Proc. Natl. Acad. Sci. Phytochem. 7: 1-45. 1982. Conservation and duplication of isozymes in plants. Science 
(Washington, D.C.), 216: 373-380. GRANTV, . 1981. Plant speciation. 2nd ed. Columbia University Press, New York.

GRAYA, . J., R. J. PARSELLa,n d R. SCOTT.1 979. The genetic structure of plant populations in relation to the development of salt marshes. In Ecological processes in coastal environments. Edited by R. L. Jefferies and A. J. Davy. Blackwell Scientific Publications, Oxford. pp. 43-64.

HARBERDD, . J. 1967. Observations on natural clones of Holcus mollis. New Phytol. 66: 401408.

HOLMBERG0,. R. 1926. Hartmans Handbok i Skandinaviens Flora, Haftel 1. P. A. Norstedt, Stockholm. HULTBN, E. 1968. Flora of Alaska andmeighbouring terri - tories. Stanford University Press, Stanford.

JEFFERIESR, . L. 1977. The vegetation of salt marshes at some coastal sites in arctic North America. J. Ecol. 65: 661-672.

JEFFERIESR, . L., A. JENSEN, a nd K. ABRAHAM1.9 79. Vegetational development and the effect of geese on vegetation at La PCrouse Bay, Manitoba. Can. J. Bot. 57: 1439-1450.

LID, J. 1952. Norsk Flora. 2nd ed. Det Norske Samlaget, Oslo.

POLUNINN, . 1940. Botany of the Canadian eastern Arctic 1. Pteridophyta and Spermatophyta. Natl. Mus. Can. Bull. 92.

SHAW,C . R., and R. PRASAD1. 970. Starch gel electrophoresis of enzymes-a compilation of recipes. Biochem. Genet. 4: 297-320.

SILANDERJ,. 1979. Microevolution and clone structure in Spartina patens. Science (Washington, D.C.), 203: 658- 660.

SOLBRIGO, . T., and B. B. SIMPSON1. 974.

Components of regulation of a population of dandelions in Michigan. J. Ecol. 62: 473-486.
SORENSETN., 1953. A revision of the Greenland species of Puccinellia Parl. Medd. Groenl. 136: 1- 179.

SVOBODAJ.,, and B. FREEDMA(NE ditors). 1981. Ecology of a high Arctic lowland oasis, Alexandra Fiord (78"53'N, 75"55'W), Ellesmere Island, N.W.T., Canada. Progress Report, Departments of Botany, University of Toronto and Dalhousie University, Toronto and Halifax.

WEEDEN, N. F., and L. D. GOTTLIEB. 1980. Genetics of chloroplast isozymes. J. Hered. 71: 392-396.

Wu, L., A. D. BRADSHAWan,d D. A.

THURMAN19. 75. The potential for evolution of heavy metal tolerance in plants. 111 . The rapid evolution of copper tolerance in Agrostis stolonifera. Heredity, 34: 165- 187. 